\title{
ULTRABAZICKÉ HORNINY TĚŠÍNITOVÉ ASOCIACE V ZÁPADNÍ ČÁSTI SLEZSKÉ JEDNOTKY
}

\author{
David Buriánek', Kamil Kropáč², Zdeněk Dolníček² \\ 'Česká geologická služba, Leitnerova 22, 65859 Brno; e-mail: david.burianek@geology.cz \\ ${ }^{2}$ Katedra geologie PřF UP, tř. 17. listopadu 12, 77146 Olomouc
}

Ultrabasic rocks of the teschenite association in the western part of the Silesian Unit

(25-12 Hranice, 25-21 Nový Jičín)

Key words: Silesian Unit, ultrabasic rocks, teschenite association, mineralogy, petrology, thermometry

\begin{abstract}
The teschenite association occurring in southwest part of the Silesian Unit (Carpathian Flysch Belt) consists of several types of predominantly alkaline basic to ultrabasic intrusive and extrusive igneous rocks. Ultrabasic rocks such as peridotites and picrites represent geochemically relatively primitive melt. Primary magmatic mineral assemblages of ultrabasic rocks are characterized by a large amount of olivine (Fo 81-86 mol. \%), clinopyroxene (predominantly diopside: $X_{M g}=0.65-0.85, \mathrm{Na}=0.02-0.04$ apfu; aegirine-augite sometimes forms small rims around diopside: $X_{M g}=0.00-0.14, \mathrm{Na}=0.40-0.98$ apfu) and rare chrome spinel to chromite with $\mathrm{Cr} /(\mathrm{Cr}+\mathrm{Al})$ values $0.55-0.62$ in peridotite or $0.26-0.69$ in picrites. Olivine, clinopyroxenes or spinelides in these rocks appear as suitable for calculation of PT conditions. The temperatures obtained using the olivine-clinopyroxene thermobarometry (1 294-1 $322^{\circ} \mathrm{C}$; 8-11 kbar) are consistent with the appearance of these two minerals in the crystallization sequence of peridotite. However, the temperatures calculated for spinelide inclusions in olivine are $\sim 50{ }^{\circ} \mathrm{Clower}$ than the experimentally derived liquidus for ultrabasic melt. This difference can be explained by subsolidus re-equilibration during cooling. Younger mineral assemblage in peridotite consists of phlogopite, pargasite, and magnetite.
\end{abstract}

\section{Úvod}

Horniny těšínitové asociace tvoří většinou plošně malé výskyty situované především ve svrchní části hradištského souvrství slezské jednotky, které sedimentovalo ve valanginu až aptu (Eliáš et al. 2003). Na základě radiometrického datování bylo určeno stárí vyvřelých hornin na 138-120 Ma (Grabowski et al. 2006, Lucińska - Anczkiewicz et al. 2002).

Podle chemického a izotopického složení bylo magma generováno parciálním tavením pláštového zdroje bohatého granátem $\mathrm{v}$ hloubkách $60-80 \mathrm{~km}$ a následně prošlo frakční krystalizací (Narebski 1990, Dostal - Owen 1998). Vznik hornin těšínitové asociace bývá spojován s časnými stádii riftingu (Narebski 1990, Kudělásková et al. 1993). Zmíněný rifting se však již dále nerozvíjel a nebyl následován oceanizací kůry a rozšiřováním oceánského dna („spredingem“; Nemčok et al. 2001).

Chemické složení hornin je velmi variabilní a dominují zde alkalické bazické až ultrabazické vyvřeliny. Tato diverzifikace bývá vysvětlována frakční krystalizací a asimilací (Hovorka - Spišiak 1988, Narebski 1990, Dostal - Owen 1998, Spišiak - Hovorka 1997). Z tohoto hlediska představují ultrabazické horniny materiál, který je těmito procesy ovlivněn nejméně. Proto byly pro studium podmínek krystalizace zvoleny vzorky pikritů z Choryně (DH69), Hodslavic (DH3011), Hončovy hůrky (Pikr-6) a také vzorek peridotitu z lokality Perná (DH2511). Cílem je zjistit, jaké procesy ovlivnily utváření minerální asociace těchto ultrabazických hornin během krystalizace a v podmínkách subsolidu.

\section{Materiál a metodika}

Analýzy minerálů byly provedeny na elektronové mikrosondě Cameca Camebax SX-100, Ústav geologic- kých věd PřF MU, Brno (operátor: Š. Benedová). Měření probíhalo ve vlnově disperzním módu za podmínek: urychlovací napětí $15 \mathrm{kV}$, průměr elektronového svazku $5 \mu \mathrm{m}$, proud $20 \mathrm{nA}$, načítací čas 20 sekund. Při vyhodnocení bylo pro amfiboly užito platné klasifikace (Leake et al. 1997) a trojmocné železo bylo počítáno metodou $13 \mathrm{eCNK}$ (Schumacher 1996). Pyroxeny (tab. 1) klasifikované podle Morimota et al. (1988) jsou počítány na 6 kyslíků a trojmocné železo je přepočteno podle Droopa (1987). Spinelidy (tab. 2) byly přepočteny na $4 \mathrm{O}, \mathrm{Fe}^{2+}$ a Fe $\mathrm{F}^{3+}$ bylo rozpočteno na základ tří kationtů ve vzorci a normalizovány na 1 kationt v pozici A. Použité zkratky minerálů jsou podle Kretze (1983).

\section{Geologická pozice vulkanitů}

Pikrity tvoří podmořské výlevy, vulkanoklastika (pyroklastické usazeniny a vulkanoklastické sedimenty) a často také žíly o mocnosti do několika metrů. Jeden z nejlépe odkrytých podmořských výlevů vystupuje v lomu na Hončově hůrce u Skotnice (vzorek: Pikr-6). Nacházejí se zde polštářové lávy a mezi nimi zachované drobné kapsy s karbonáty nebo kontaktně metamorfovanými sedimenty. Okraje lávových polštářủ jsou prudce zchlazené a původní sklovitá hornina je výrazně postižena sekundárními přeměnami. Ve středech polštářů však nacházíme poměrně dobře zachovalé pikrity, někdy s vyrostlicemi olivínu. Podobné podmořské výlevy jsou také odkryty u Hodslavic (na okraji bývalé železniční trati, vzorek: DH3011). Zde jsou navíc v polštářových lávách lokálně poměrně hojné drobné varioly. Na lokalitě Choryně pikrity obsahují xenolity kontaktně metamorfovaného silicitu (95 až 99 mod. \% tvoří drobně zrnitý křemen a zbytek chlority, oxidy a oxohydroxidy železa) a kontaktních rohovců (vzorek: DH69). 
Tab. 1: Reprezentativní chemické složení pyroxenů.

Tab. 1: Representative chemical composition of pyroxenes.

\begin{tabular}{|l|r|r|r|r|r|r|r|r|r|}
\hline Vzorek & DH69_33 & DH69_55 & DH69_64 & DH69_63 & Pikr-6 & DH3011 & DH2511 & DH2511 & DH2511 \\
\hline $\mathrm{SiO}_{2}$ & 45,78 & 45,54 & 46,45 & 49,83 & 46,04 & 45,26 & 40,22 & 44,06 & 50,33 \\
\hline $\mathrm{TiO}_{2}$ & 2,75 & 2,76 & 2,10 & 1,12 & 3,27 & 3,09 & 6,18 & 4,13 & 1,48 \\
\hline $\mathrm{Al}_{2} \mathrm{O}_{3}$ & 6,61 & 6,67 & 5,87 & 0,31 & 6,63 & 8,27 & 11,63 & 9,05 & 4,18 \\
\hline $\mathrm{Cr}_{2} \mathrm{O}_{3}$ & 0,03 & 0,01 & 0,01 & 0,04 & 0,00 & 0,03 & 0,02 & 0,36 & 0,90 \\
\hline $\mathrm{FeOt}$ & 7,42 & 8,06 & 6,83 & 24,47 & 8,64 & 11,37 & 8,09 & 6,31 & 4,68 \\
\hline $\mathrm{MnO}$ & 0,12 & 0,15 & 0,17 & 1,40 & 0,14 & 0,19 & 0,12 & 0,07 & 0,02 \\
\hline $\mathrm{MgO}$ & 13,20 & 12,57 & 13,26 & 2,25 & 12,04 & 11,93 & 9,92 & 12,17 & 15,01 \\
\hline $\mathrm{CaO}$ & 23,97 & 23,83 & 24,07 & 13,70 & 22,94 & 20,23 & 22,91 & 23,19 & 23,56 \\
\hline $\mathrm{Na}_{2} \mathrm{O}$ & 0,33 & 0,41 & 0,37 & 5,24 & 0,51 & 0,43 & 0,52 & 0,45 & 0,31 \\
\hline $\mathrm{K}_{2} \mathrm{O}$ & 0,00 & 0,02 & 0,00 & 0,00 & 0,05 & 0,01 & 0,03 & 0,03 & 0,00 \\
\hline $\mathrm{Celkem}$ & 100,21 & 100,02 & 99,13 & 98,35 & 100,26 & 100,81 & 99,63 & 99,83 & 100,47 \\
\hline $\mathrm{Si}$ & 1,696 & 1,695 & 1,735 & 1,975 & 1,718 & 1,687 & 1,520 & 1,641 & 1,843 \\
\hline${ }^{\mathrm{IV}} \mathrm{Al}$ & 0,289 & 0,293 & 0,258 & 0,015 & 0,282 & 0,313 & 0,480 & 0,359 & 0,157 \\
\hline${ }^{\mathrm{V}} \mathrm{Al}$ & 0,000 & 0,000 & 0,000 & 0,000 & 0,009 & 0,050 & 0,038 & 0,039 & 0,023 \\
\hline $\mathrm{Ti}$ & 0,077 & 0,077 & 0,059 & 0,033 & 0,092 & 0,087 & 0,176 & 0,116 & 0,041 \\
\hline $\mathrm{Fe}{ }^{3+}$ & 0,189 & 0,192 & 0,181 & 0,369 & 0,129 & 0,121 & 0,129 & 0,112 & 0,048 \\
\hline $\mathrm{Cr}$ & 0,001 & 0,000 & 0,000 & 0,001 & 0,000 & 0,001 & 0,001 & 0,011 & 0,026 \\
\hline $\mathrm{Fe}{ }^{2+}$ & 0,040 & 0,059 & 0,033 & 0,442 & 0,141 & 0,234 & 0,126 & 0,085 & 0,095 \\
\hline $\mathrm{Mg}$ & 0,729 & 0,698 & 0,738 & 0,133 & 0,669 & 0,663 & 0,559 & 0,676 & 0,819 \\
\hline $\mathrm{Mn}$ & 0,004 & 0,005 & 0,005 & 0,047 & 0,004 & 0,006 & 0,004 & 0,002 & 0,001 \\
\hline $\mathrm{Ca}$ & 0,951 & 0,950 & 0,963 & 0,582 & 0,917 & 0,808 & 0,927 & 0,926 & 0,924 \\
\hline $\mathrm{Na}$ & 0,024 & 0,030 & 0,027 & 0,402 & 0,037 & 0,031 & 0,038 & 0,033 & 0,022 \\
\hline $\mathrm{K}$ & 0,000 & 0,001 & 0,000 & 0,000 & 0,002 & 0,000 & 0,001 & 0,001 & 0,000 \\
\hline$\Sigma \mathrm{Kat}$ & 4,000 & 4,000 & 4,000 & 4,000 & 4,000 & 4,000 & 4,000 & 4,000 & 4,000 \\
\hline $\mathrm{Wo}$ & 49 & 49 & 49 & 29 & 48 & 43 & 52 & 50 & 48 \\
\hline $\mathrm{En}$ & 38 & 36 & 38 & 7 & 35 & 36 & 31 & 37 & 43 \\
\hline $\mathrm{Fs}$ & 12 & 13 & 11 & 43 & 14 & 19 & 15 & 11 & 8 \\
\hline $\mathrm{Ae}$ & 1 & 2 & 1 & 20 & 2 & 2 & 2 & 2 & 1 \\
\hline & & & & & & & & & \\
\hline
\end{tabular}

vic (DH3011) byly v základní hmotě nalezeny až $5 \mathrm{~mm}$ velké varioly, které obsahují drobné kostrovité krystaly („swallow-tail“, obr. 1c) oligoklasu až andezínu $\left(\mathrm{Ab}_{29-38}\right)$. Základní hmota byla původně patrně sklovitá, avšak dnes je $\mathrm{z}$ velké části tvořena drobnými lupínky Mg-chloritu srůstajícími s dalšími sekundárními minerály (minerály serpentinové skupiny, kalcitem a již zmíněnými živci). Některé vzorky obsahují drobné mandle (kolem $5 \mathrm{~mm}$ ) vyplněné vrstvičkami kalcitu a chloritu. Automorfní až oválné vyrostlice olivínu bývají často nahrazeny minerály serpentinové skupiny, chlority (často ve směsi se smektitem, D. Matýsek pers. comm.), karbonátem a blíže neidentifikovanou směsí oxidů a hydroxidů $\mathrm{Fe}$ a Ti. Č́st olivínu se zachovala jen ve vzorku Pikr-6. Tento olivín má poměrně homogenní

Peridotit na lokalitě Perná vystupuje pouze v podobě složení (Fo 86 mol. \%). Automorfní až hypautomorfní drobných úlomků na louce. Přesná pozice a tvar tělesa vyrostlice pyroxenu mají oscilační zonálnost. Většinou nejsou známy (vzorek: DH2511). Úlomky se vyskytují na ploše asi $50 \mathrm{~m}^{2}$. Může se tedy jednat o drobné těleso nebo několik xenolitů vynesených vulkanity k povrchu.

\section{Petrografická charakteristika Pikrity}

Pikrit je drobně až středně zrnitá ultrabazická výlevná hornina, která je tvořena hlavně olivínem (obr. 1a). Dále je zastoupen v proměnlivém množství klinopyroxen, amfibol a biotit. V podružném a akcesorickém množství se vyskytuje plagioklas, ilmenit, magnetit, apatit, vzácně analcim a perowskit (D. Matýsek pers. comm.). Olivín a někdy také klinopyroxen nebo amfibol tvoří automorfní vyrostlice v jemnozrnné až afanitické základní hmotě, která je tvořena sekundárními minerály (obr. 1b). Sekundární xenomorfní až hypautomorfní živce jsou vzácné a svým chemickým složením odpovídají albitu $\left(\mathrm{Ab}_{100}\right)$ nebo ortoklasu $\left(\mathrm{Ab}_{6}\right)$. Ve vzorku z Hodsla-
Tab. 2: Reprezentativní chemické složení spinelidů.

Tab. 2: Representative chemical composition of spinelides.

\begin{tabular}{|l|r|r|r|r|r|r|r|r|r|}
\hline Vzorek & DH69 & DH69 & DH69 & DH2511 & DH2511 & DH2511 & Pikr-6 & Pikr-6 & DH3011 \\
\hline $\mathrm{SiO}_{2}$ & 0,25 & 0,12 & 0,09 & 0,06 & 0,07 & 0,08 & 0,16 & 0,14 & 0,13 \\
\hline $\mathrm{TiO}_{2}$ & 6,03 & 6,01 & 1,43 & 3,32 & 8,10 & 2,20 & 1,83 & 1,40 & 2,42 \\
\hline $\mathrm{Al}_{2} \mathrm{O}_{3}$ & 11,58 & 12,12 & 33,63 & 6,86 & 11,41 & 17,14 & 34,95 & 31,42 & 12,59 \\
\hline $\mathrm{Cr}_{2} \mathrm{O}_{3}$ & 13,93 & 14,80 & 24,65 & 8,13 & 16,09 & 30,72 & 21,69 & 27,22 & 40,40 \\
\hline $\mathrm{V}_{2} \mathrm{O}_{3}$ & 0,11 & 0,16 & 0,12 & 0,27 & 0,30 & 0,17 & 0,13 & 0,17 & 0,19 \\
\hline $\mathrm{NiO}$ & 0,10 & 0,12 & 0,18 & 0,10 & 0,22 & 0,18 & 0,28 & 0,18 & 0,20 \\
\hline $\mathrm{FeOt}$ & 54,66 & 53,80 & 23,25 & 72,79 & 50,01 & 37,30 & 23,11 & 22,68 & 30,80 \\
\hline $\mathrm{MnO}$ & 0,76 & 0,80 & 0,26 & 0,59 & 0,35 & 0,33 & 0,25 & 0,24 & 0,29 \\
\hline $\mathrm{MgO}$ & 7,89 & 6,13 & 15,47 & 3,15 & 9,24 & 9,22 & 16,05 & 15,55 & 10,77 \\
\hline $\mathrm{CaO}$ & 0,18 & 0,15 & 0,13 & 0,00 & 0,15 & 0,00 & 0,01 & 0,07 & 0,39 \\
\hline $\mathrm{ZnO}$ & 0,12 & 0,12 & 0,19 & 0,14 & 0,09 & 0,11 & 0,18 & 0,02 & 0,10 \\
\hline $\mathrm{Celkem}$ & 95,63 & 94,32 & 99,40 & 95,41 & 96,02 & 97,45 & 98,65 & 99,09 & 98,25 \\
\hline $\mathrm{Fe}{ }^{2+}$ & 0,728 & 0,807 & 0,347 & 0,899 & 0,719 & 0,591 & 0,336 & 0,343 & 0,509 \\
\hline $\mathrm{Mn}$ & 0,022 & 0,024 & 0,006 & 0,018 & 0,010 & 0,009 & 0,006 & 0,006 & 0,008 \\
\hline $\mathrm{Mg}$ & 0,401 & 0,319 & 0,668 & 0,169 & 0,465 & 0,449 & 0,692 & 0,679 & 0,526 \\
\hline $\mathrm{Ca}$ & 0,007 & 0,006 & 0,004 & 0,000 & 0,006 & 0,000 & 0,000 & 0,002 & 0,014 \\
\hline $\mathrm{Zn}$ & 0,003 & 0,003 & 0,004 & 0,004 & 0,002 & 0,003 & 0,004 & 0,000 & 0,002 \\
\hline $\mathrm{Ni}$ & 0,003 & 0,003 & 0,004 & 0,003 & 0,006 & 0,005 & 0,006 & 0,004 & 0,005 \\
\hline $\mathrm{Ti}$ & 0,009 & 0,004 & 0,003 & 0,002 & 0,002 & 0,003 & 0,005 & 0,004 & 0,004 \\
\hline $\mathrm{Si}$ & 0,155 & 0,158 & 0,031 & 0,090 & 0,206 & 0,054 & 0,040 & 0,031 & 0,060 \\
\hline $\mathrm{Al}$ & 0,465 & 0,499 & 1,149 & 0,290 & 0,454 & 0,660 & 1,190 & 1,084 & 0,486 \\
\hline $\mathrm{Cr}$ & 0,375 & 0,409 & 0,565 & 0,231 & 0,429 & 0,794 & 0,496 & 0,630 & 1,047 \\
\hline $\mathrm{V}$ & 0,003 & 0,004 & 0,003 & 0,008 & 0,008 & 0,005 & 0,003 & 0,004 & 0,005 \\
\hline $\mathrm{Fe}{ }^{3+}$ & 0,830 & 0,764 & 0,216 & 1,287 & 0,692 & 0,429 & 0,222 & 0,212 & 0,335 \\
\hline $\mathrm{LKat}$. & 3,000 & 3,000 & 3,000 & 3,000 & 3,000 & 3,000 & 3,000 & 3,000 & 3,000 \\
\hline
\end{tabular}



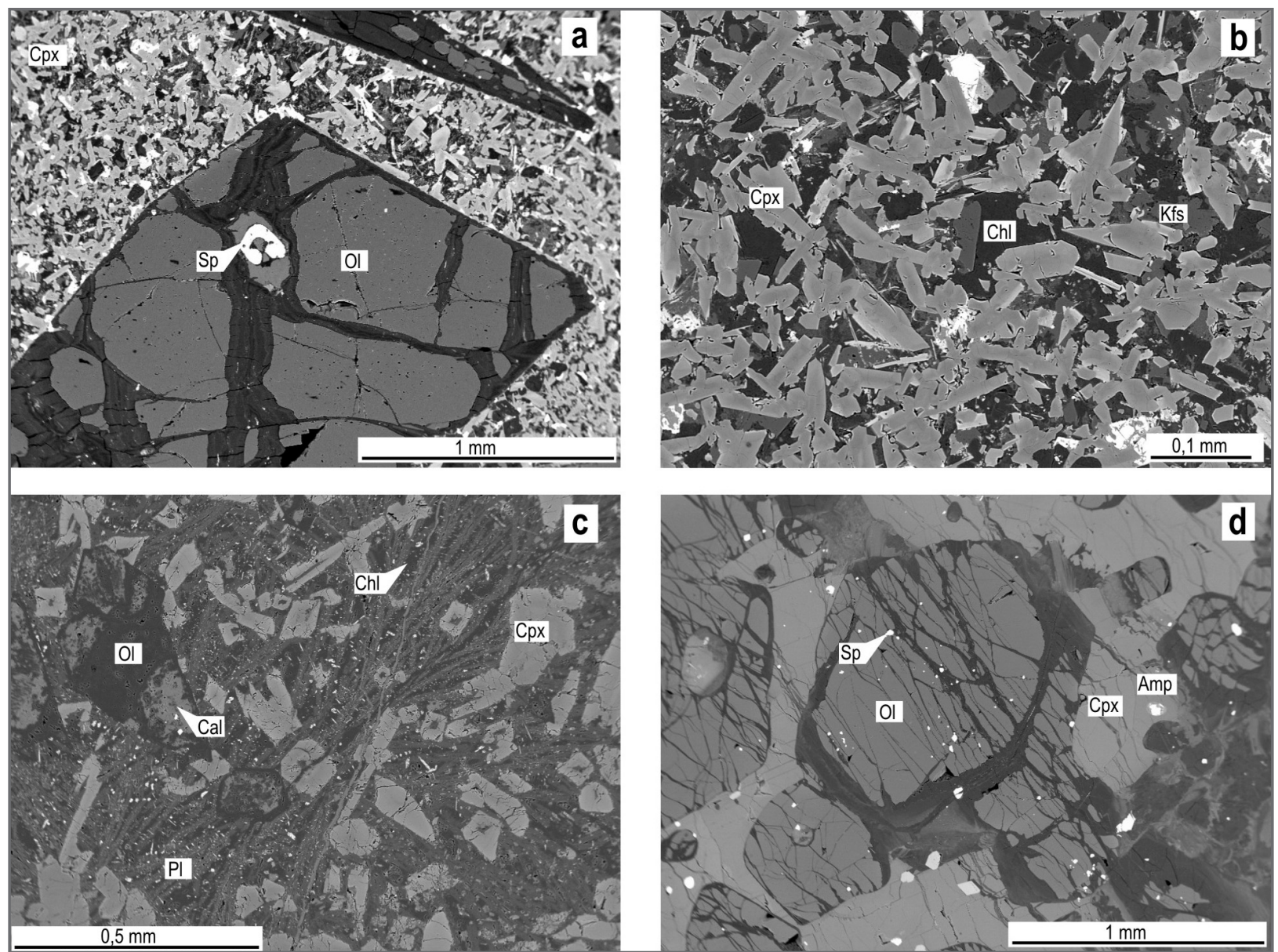

Obr. 1: Pikrity (a-c) a peridotit (d) v BSE snímcích z lokalit Hončova hůrka (a-b, Pikr-6), Hodslavice (c, DH3011) a Perná (d, DH2511): a - vyrostlice částečně serpentinizovaného olivínu s inkluzemi Cr-spinelu v pikritu; b - základní hmota pikritu je přeměněna na agregáty zrn chloritu, klinopyroxenu, draselného živce a opakní minerály; $\mathrm{c}$ - drobné vyrostlice olivínu (zcela přeměněné na směs minerálů serpentinové skupiny a kalcitu) a kostrovité krystaly plagioklasu; $\mathrm{d}$ - automorfní olivín (Ol) obklopený interkumulem tvořeným klinopyroxenem (Cpx) a amfibolem (Amp).

Fig. 1: Picrites and peridotite in BSE images from the localities Hončova hůrka (a-b, Pikr-6), Hodslavice (c, DH3011) and Perná (d, DH2511): a - partially serpentinized olivine phenocryst enclosing the Cr-spinel in picrite; $\mathrm{b}$ - picrite groundmass is altered to an aggregate of chlorite, clinopyroxene, K-feldspars and opaque minerals; $\mathrm{c}$ - minor olivine phenocrysts (completely replaced to a mixture of minerals of the serpentine group and calcite) and skeletal plagioclase crystals from the locality; $\mathrm{d}$ - euhedral olivine phenocrysts (Ol) surrounded by intercumulus composed of clinopyroxene (Cpx) and amphibole (Amp).

chemicky odpovídají diopsidu $\left(\mathrm{X}_{\mathrm{Mg}}=0,65-0,78 ; \mathrm{Ti}=\right.$ 0,06-0,16 apfu; $\mathrm{Na}=0,02-0,04$ apfu; obr. 2a, b). Vzácně se na okrajích objevuje tenký lem, který má složení egirín-augit $\left(\mathrm{X}_{\mathrm{Mg}}=0,00-0,14 ; \mathrm{Ti}=0,03-0,13 \mathrm{apfu} ; \mathrm{Na}=\right.$ 0,40-0,98 apfu). V základní hmotě se někdy vyskytují drobné sloupce amfibolu (kaersutit; $\mathrm{Si}=5,8-6,0$ apfu; $\mathrm{X}_{\mathrm{Mg}}$ $=0,58-0,70 ; \mathrm{Ti}=0,59-0,69 \mathrm{apfu})$. Biotit je vzácný a bývá většinou postižen chloritizací. Zachované relikty mají složení Mg-annitu $\left(\mathrm{X}_{\mathrm{Mg}}=0,47\right.$; $\left.{ }^{\mathrm{IV}} \mathrm{Al}=2,95 \mathrm{apfu}\right)$. Jako hojný akcesorický minerál se vyskytuje automorfní až hypautomorfní spinelid. Jeho zrna vykazují jednoduchou zonálnost. Ve střední části je zachován chromový spinel $(\mathrm{Al}=1,0-1,2$; $\mathrm{Fe}^{3+}=0,2 ; \mathrm{Cr}=0,5-0,7$ apfu; obr. 2c, d) a v tenkém lemu je často magnetit. V základní hmotě je tento zonální spinelid doprovázen magnetitem někdy s vysokým obsahem ulvöspinelové komponenty $\left(\mathrm{Al}=0,2 ; \mathrm{Ti}=0,4 ; \mathrm{Fe}^{3+}=0,9\right)$. U spinelidu, který tvoří inkluze v olivínech, není magnetitový lem vyvinut. Na lokalitě Hodslavice (DH3011) jsou př́tomny pouze nezonální $\mathrm{Al}$-chromity $(\mathrm{Al}=0,5$;
$\mathrm{Fe}^{3+}=0,3 ; \mathrm{Cr}=1,0$ apfu; obr. 2c, d). Ve všech studovaných vzorcích se místy objevují jehlicovité krystalky fluorapatitu ( $\mathrm{F}=1,8-2,2$ hmot. \%) a automorfní titanit.

\section{Peridotit}

Peridotit je černá až rezavě šedá stř̌edně zrnitá hornina. Nezvětralé vzorky vykazují velmi nízký stupeň postižení sekundárními alteracemi. Hornina má kumulátovou stavbu (obr. 1d), přičemž kumulus (68 mod. \%) tvoří automorfní až hypautomorfní zrna olivínu (Fo 81-84 mol. \%). Interkumulus se pak skládá z klinopyroxenu, amfibolu a biotitu. Klinopyroxen chemicky odpovídá diopsidu $\left(X_{M g}=0,69-0,85 ; \mathrm{Ti}=0,04-0,18\right.$ apfu; $\mathrm{Na}=0,02-0,04$ apfu; obr. 2a, b). Amfibol srůstá s pyroxenem (často je patrné, že pyroxen je amfibolem zatlačován) a má poměrně homogenní chemické složení odpovídající pargasitu $(\mathrm{Si}=$ 5,7-6,1 apfu; $\mathrm{X}_{\mathrm{Mg}}=0,76-0,80 ; \mathrm{Ti}=0,28-0,64 \mathrm{apfu}$ ). Biotit tvoří agregáty drobných lupínků většinou uzavřené $\mathrm{v}$ amfibolech. Svým chemickým složením odpovídá flogopitu 

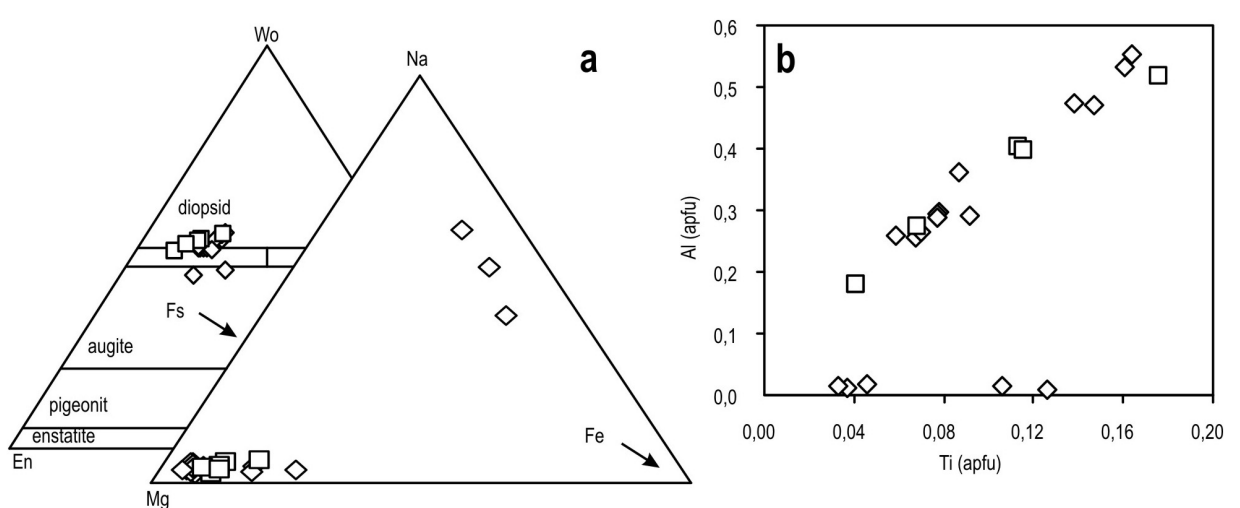

roxenem. Klinopyroxen přitom většinou uzavírá olivín a chromit, avšak zároveň je částečně zatlačován mladší minerální asociací reprezentovanou pargasitem, flogopitem a magnetitem. Pro starší minerální asociaci bylo možné, podobně jako u pikritů, využít spinel-
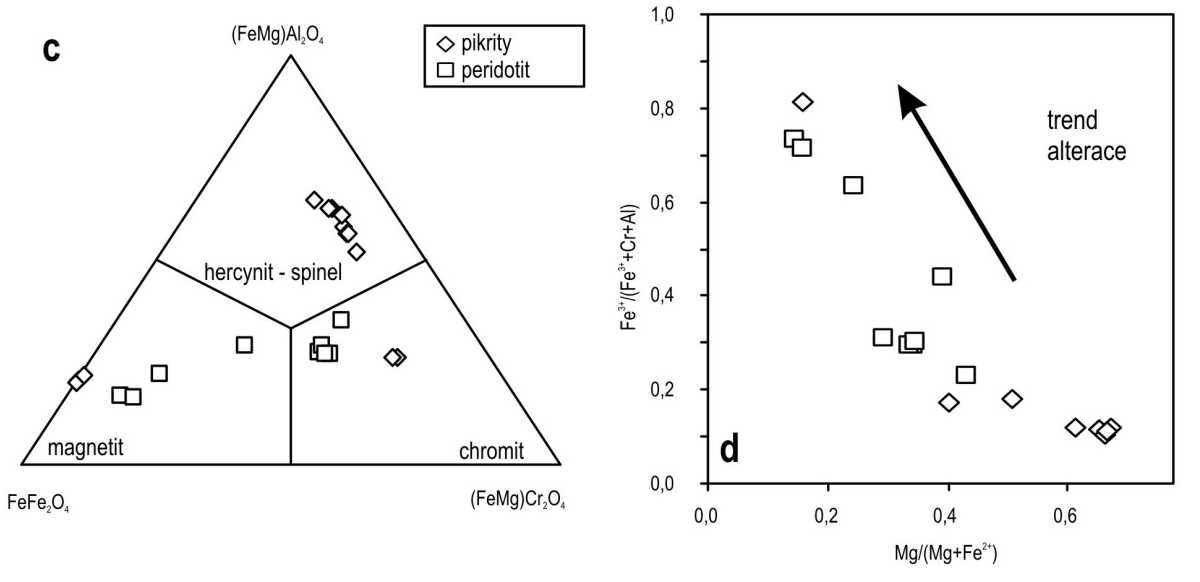

Obr. 2: Chemické složení minerálů v pikritech (1) a peridotitu (2): a - diagramy Wo-En-Fs a Fe-Mg-Na pro pyroxeny; $\mathrm{b}$ - diagram Ti vs. Al pro pyroxeny; $\mathrm{c}$ - trojúhelníkový diagram ( $\mathrm{FeMg}) \mathrm{Cr}_{2} \mathrm{O}_{4}-\mathrm{FeFe}_{2} \mathrm{O}_{4}$ - $(\mathrm{FeMg}) \mathrm{Al}_{2} \mathrm{O}_{4}$ pro spinelidy; $\mathrm{d}-\mathrm{Fe}^{3+} /\left(\mathrm{Fe}^{3+}+\mathrm{Cr}+\mathrm{Al}\right)$ vs. $\mathrm{Mg} /\left(\mathrm{Mg} / \mathrm{Fe}^{2+}\right)$ diagram pro spinelidy.

Fig. 2: Chemical composition of minerals from picrites (1) and peridotite (2): a - triangular Wo-En-Fs and $\mathrm{Na}-\mathrm{Mg}$-Fe plots for pyroxenes; $\mathrm{b}$ - Ti vs. Al plot for pyroxenes; $\mathrm{c}$ - triangular $(\mathrm{FeMg}) \mathrm{Cr}_{2} \mathrm{O}_{4}-\mathrm{FeFe}_{2} \mathrm{O}_{4}$ - (FeMg) $\mathrm{Al}_{2} \mathrm{O}_{4}$ plot for spinelides; (d) $\mathrm{Fe}^{3+} /\left(\mathrm{Fe}^{3+}+\mathrm{Cr}+\mathrm{Al}\right) \mathrm{vs}$. $\mathrm{Mg} /\left(\mathrm{Mg} / \mathrm{Fe}^{2+}\right)$ plot for spinelides.

$\left(\mathrm{X}_{\mathrm{Mg}}=0,77-0,79 ;{ }^{\mathrm{IV}} \mathrm{Al}=2,38-2,51 \mathrm{apfu}\right)$. Poměrně běžnou inkluzí v olivínech a klinopyroxenech je chromit $(\mathrm{Al}=0,5-$ 0,$7 ; \mathrm{Fe}^{3+}=0,4-0,5 ; \mathrm{Cr}=0,7-0,8$ apfu; obr. $\left.2 \mathrm{c}, \mathrm{d}\right)$. V amfibolu a v biotitu se pak vyskytuje magnetit $\left(\mathrm{Al}=0,3-0,5 ; \mathrm{Fe}^{3+}=\right.$ 1,3-0,7; Cr = 0,2-0,4 apfu; obr. 2c, d), který často uzavírá drobné inkluze amfibolu nebo klinopyroxenu. Olivín je místy postižen serpentinizací a flogopit chloritizací. Tyto přeměny jsou však relativně malé.

\section{Podmínky krystalizace ultrabazických hornin}

Při výzkumu ultrabazických hornin byly cíleně vyhledávány inkluze spinelidů v olivínu. Vyrostlice olivínu totiž začaly krystalovat ještě hluboko pod povrchem v magmatickém krbu a inkluze, které uzavřely, mohou nést informace o hloubkách, v nichž bylo ultrabazické magma generováno. Jako velmi nadějné se jevily zejména inkluze chromových spinelů v pikritu z Hončovy hůrky. Pomocí dvou spinel-olivínových termometrů (Ballhaus et al. 1991 a O'Neill - Wall 1987) byly vypočteny podobné teploty zhruba mezi $737-838^{\circ} \mathrm{C}$ (tab. 3). Poněkud širší rozsah teplot $\left(733-904^{\circ} \mathrm{C}\right)$ poskytl spinelový termometr založený na obsazích Zn (Ryan et al. 1996).

V peridotitu můžeme odlišit dvě minerální asociace. Starší je reprezentována chromitem, olivínem a klinopynopyroxenu (tab. 1). Základní hmotu původně tvořilo vulkanické sklo, pyroxeny a někdy také živce. Tyto primární oligoklasy až andezíny vytvořily v důsledku rychlé krystalizace kostrovité krystaly („swallow-tail“), které se často koncentrovaly v kulovitých útvarech - variolách (Buriánek - Bubík 2012). Vulkanické sklo v základní hmotě je dnes přeměněno na sekundární minerály (hlavně chlority a často také sekundární alkalické živce). Ve vyrostlicích olivínu i v základní hmotě jsou spinelidy. V olivínech jsou uzavřeny chromové spinely až chromity $[\mathrm{Cr} /(\mathrm{Cr}+\mathrm{Al})=$ $0,26-0,69]$. V základní hmotě je společně se spinelem př́tomen magnetit. Teploty vypočtené pro inkluze chromového spinelu v olivínu z pikritu (Hončova hůrka u Skotnice)

Tab. 3: Výsledky výpočtů P-T podmínek.

Tab. 3: Results of P-T calculations.

\begin{tabular}{|l|c|c|}
\hline vzorek & Pikr6 & DH2511 \\
\hline kalibrace & \multicolumn{2}{|c|}{ geotermometr $\left({ }^{\circ} \mathrm{C}\right)$} \\
\hline Koehler-Brey (1990) Cpx-Ol & - & $1294-1322$ \\
\hline O'Neill-Wall (1987) Ol-Sp & $741-821$ & $695-826$ \\
\hline Ballhaus et al. (1991) Ol-Sp & $737-838$ & $690-833$ \\
\hline Ryan et al. (1996) Zn ve Sp & $733-904$ & $718-982$ \\
\hline & \multicolumn{2}{|c|}{ geobarometr (kbar) } \\
\hline Koehler-Brey (1990) Cpx-Ol & - & $8-11$ \\
\hline
\end{tabular}


jsou poměrně nízké $\left(733-904{ }^{\circ} \mathrm{C}\right)$ na to, aby indikovaly podmínky krystalizace ultrabazických hornin. Je tedy pravděpodobné, že zde došlo během chladnutí magmatu k reekvilibraci chemického složení olivínů a spinelů. Další možností je, že byly spinely uzavřeny v olivínu během konvekčního proudění v magmatickém krbu a oba minerály tedy nejsou v rovnováze.

Peridotit pravděpodobně reprezentuje horninu utuhlou ve větší hloubce, čemuž odpovídá struktura horniny a také P-T podmínky (1 294-1 $322{ }^{\circ} \mathrm{C} ; 8-11 \mathrm{kbar}$ ) zjištěné na základě olivín-klinopyroxenového termometru a barometru (Koehler - Brey 1990). Poněkud nižší teploty $\left(1260-950{ }^{\circ} \mathrm{C}\right)$ uvádí pro krystalizaci pikritů a těšínitů Wlodyka (2010). Kumulátová stavba naznačuje krystalizaci $\mathrm{v}$ rozsáhlejším magmatickém krbu a do dnešní pozice se peridotit dostal $\mathrm{v}$ důsledku tektonických pohybů nebo byl vynesen $v$ podobě xenolitu magmatem $\mathrm{k}$ povrchu. Bohužel špatná odkrytost terénu neumožňuje jednoznačnou interpretaci. V každém př́padě vypočtené $\mathrm{P}$-T podmínky poměrně dobře odpovídají teplotám solidu peridotitu v hloubkách kolem $35 \mathrm{~km}$ (Herzberg 1995). Amfibol a flogopit $v$ takovém peridotitu mohou krystalovat během výstupu $\mathrm{k}$ povrchu a to při teplotách pod $1100^{\circ} \mathrm{C}$ (Sato et al. 1997). Amfibol totiž může vznikat za subsolidových podmínek $\mathrm{v}$ důsledku reakce: pargasit $=$ klinopyroxen + olivín + spinel + tavenina (Foden - Green 1992). Není však také vyloučeno, že $\mathrm{k}$ těmto přeměnám došlo až v podmínkách na mořském dně nebo těsně pod ním, kdy se ještě poměrně horká hornina dostala do kontaktu s mořskou nebo diagenetickou vodou (Buriánek - Bubík 2012). Poměrně dobrým indikátorem polyfázového vývoje minerální parageneze peridotitu jsou spinelidy. Zatímco v olivínu a pyroxenu jsou uzavřeny inkluze chromitu, v amfibolu byl zjištěn pouze magnetit. Z chromitu v olivínu byly vypočteny teploty $690-982^{\circ} \mathrm{C}$, které nejsou v souladu s termobarometrickými výpočty pro pár olivín-klinopyroxen. Oba minerály tedy nejsou v rovnováze, nebo zde během chladnutí došlo $\mathrm{k}$ jejich reekvilibraci (viz např. Lehmann 1983). Pozorovaná zonalita zrn chromitů [Cr/ $(\mathrm{Cr}+\mathrm{Al})=0,55-0,62$, tab. 2] indikuje spiše druhou možnost (chemické složení spinelidů $\mathrm{z}$ těchto hornin uvádí např́iklad Kamenetsky et al. 2001). Minerální složení systému se oproti horninám, pro něž byly všechny tři spinelové termometry kalibrovány, poněkud liší. Horniny např́klad neobsahují ortopyroxen (Ballhaus et al. 1991) nebo granát (Ryan et al. 1996). Svým chemickým složením (Buriánek - Bubík 2012) i minerálním složením jsou však studované horniny velmi podobné pláštovým horninám a některým pikritům, pro něž byly tyto termometry s úspěchem využity (např́iklad Ichiyama et al. 2012).

Během dalšího vývoje horniny dochází v pikritech a peridotitech $\mathrm{k}$ postupné změně chemického složení původního chromitu, což má za následek vznik zonálního spinelidu nebo vznik nových zrn magnetitu. Automorfně omezená zrna magnetitu však mohla vznikat také v průběhu magmatické krystalizace (např. Šmíd 1978). Proces přeměny chromitu na chromem bohatý magnetit nebo chromem bohatý spinel má několik fází (Farahat 2008). Za velmi nízkého stupně metamorfózy je původní chromový spinel lemován $\mathrm{v}$ důsledku prŕnosu $\mathrm{Fe}$ a odnosu Mg chromovým magnetitem. Změny chemického složení chromitu během sekundárních přeměn také závisí na minerální asociaci. Jestliže chromit koexistuje s chloritem, může při přeměnách reagovat s fluidy za vzniku chromového magnetitu a uvolněný $\mathrm{Al}$ spotřebují okolní chlority (Barnes 2000). Magnetit také může vznikat jako produkt reakcí př̀i přeměně původních magmatických minerálů na sekundární (např. serpentinizace). $V$ př́padě peridotitu mohl vznikat chromový magnetit $\mathrm{v}$ důsledku reakce produkující pargasit na úkor klinopyroxenu.

\section{Závěry}

Horniny těšínitové asociace ve slezské jednotce Západních Karpat reprezentují širokou škálu většinou alkalických bazických až ultrabazických výlevných i hlubinných hornin. Ultrabazické horniny jako pikrity a peridotity zde reprezentují geochemicky nejméně modifikovaný primitivní materiál. Minerály $\mathrm{v}$ těchto horninách nesou informace o PT podmínkách $v$ nichž krystalizovaly, a proto je můžeme využít při interpretaci jejich magmatického i postmagmatického vývoje.

Pikrity tvoří subakvatické lávové proudy charakterizované př́tomností polštářových láv a hyaloklastitů. Chemické složení minerálů a zejména spinelidů odráží tento vývoj. Inkluze v olivínech a některá zrna v základní hmotě mají složení odpovídající magmatickým chromovým spinelům. V základní hmotě je však v důsledku sekundárních přeměn chromový spinel obrůstán magnetitem či Ti-bohatým magnetitem. $V$ některých př́ípadech však není možné vyloučit ani magmatickou krystalizaci magnetitu.

Peridotit představuje enklávu vynesenou magmatem z hloubek kolem $35 \mathrm{~km}$. V této hloubce se nacházel magmatický krb, kde docházelo ke gravitační diferenciaci magmatu a vzniku kumulátů za teplot kolem $1294-1322^{\circ} \mathrm{C}$. Získaná data jsou však pouze orientační a jejich potvrzení vyžaduje další výzkum. Chemické složení spinelidů indikuje nejméně dvě fáze vývoje této horniny. $V$ olivínu a pyroxenu jsou uzavřeny inkluze chromitu, které vznikaly během magmatické krystalizace. Teploty vypočítané pro pár olivín-chromit jsou však o $\sim 500{ }^{\circ} \mathrm{C}$ nižší, než by odpovídalo podmínkám, za nichž ultrabazické horniny krystalizují. Tuto skutečnost můžeme vysvětlit reekvilibrací těchto minerálů během jejich chladnutí. Mladší amfibol a flogopit vznikaly současně s magnetitem $\mathrm{v}$ podmínkách nižších teplot.

\section{Poděkování}

Autoři děkují D. Matýskovi a A. Přichystalovi za kritické pročtení rukopisu. Práce byla vypracována s finanční podporou projektu ČGS 390004 (Základnígeologické mapování Beskyd v méř́tku 1:25 000) a GAČR 205/07/P130. 


\section{Literatura}

Ballhaus, C. - Berry, R. F. - Green, D. H. (1991): High pressure experimental calibration of the olivine-orthopyroxene-spinel-oxygen geobarometer: implications for the oxidation state of the upper mantle. - Contributions to Mineralogy and Petrology, 107, 27-40.

Barnes, S. J. (2000): Chromite in Komatiites, II. Modification during Greenschist to Mid-Amphibolite Facies Metamorphism. Journal of Petrology, 41(3), 387-409.

Buriánek, D. - Bubík, M. (2012): Horniny těšínitové asociace v okolí Valašského Meziř́čí. - Acta Musei Moraviae, Scientiae geologicae, 97, 1, 105-127. Brno.

Dostal, J. - Owen, J. V. (1998): Cretaceous alkaline lamprophyres from northeastern Czech Republic: geochemistry and petrogenesis. - Geologische Rundschau, 87, 1, 67-77.

Droop, G. T. R. (1987): A general equation for estimating $\mathrm{Fe}^{3+}$ in ferromagnesian silicates and oxides from microprobe analysis, using stoichiometric criteria. - Mineralogical Magazine, 51, 431-437.

Eliáš, M. - Skupien, P. - Vašíček, Z. (2003). Návrh úpravy litostratigrafického členění nižší části slezské jednotky na českém území (Vnější Západní Karpaty). - Sborník vědeckých prací Vysoké školy báňské - Technické univerzity Ostrava, Řada hornicko-geologická, 49, Monografie 8, 7-13. Ostrava.

Farahat, E. S. (2008): Chrome-spinels in serpentinites and talc carbonates of the El Ideid-El Sodmein District, central Eastern Desert, Egypt: their metamorphism and petrogenetic implications. - Chemie der Erde - Geochemistry, 68(2), 193-205.

Foden, J. D. - Green, D. H. (1992): Possible role of amphibole in the origin of andesite: some experimental and natural evidence. - Contributions to Mineralogy and Petrology, 109, 479-493.

Grabowski, J. - Krzemiński, L. - Nescieruk, P. - Starnawska, E. (2006): Palaeomagnetism of the teschenitic rocks (Lower Cretaceous) in the Outer Western Carpathians of Poland: constraints for tectonic rotations in the Silesian unit. - Geophysical Journal International, 166(3), 1077-1094.

Herzberg, C. (1995): Generation of plume magmas through time: an experimental perspective. - Chemical Geology, 126 (1995), 1-16. Hovorka, D. - Spišiak, J. (1988): Mezozoický vulkanizmus Západných Karpát. - 263 stran, Veda, Bratislava.

Ichiyama, Y. - Ishiwatari, A. - Kimura, J.-I. - Senda, R. - Kawabata, H., - Tatsumi, Y. (2012): Picrites in central Hokkaido: Evidence of extremely high temperature magmatism in the Late Jurassic ocean recorded in an accreted oceanic plateau. - Geology, 40(5), 411-414.

Kamenetsky, V. S. - Crawford, A. J., - Meffre, S. (2001): Factors controlling chemistry of magmatic spinel : an empirical study of associated olivine, Cr-spinel and melt inclusions from primitive rocks, Journal of Petrology, 42, 655-671.

Koehler, T. - Brey, G. P. (1990). Calcium exchange between olivine and clinopyroxene calibrated as a geothermobarometer for natural peridotites from 2 to $60 \mathrm{~kb}$ with applications. - Geochimica et Cosmochimica Acta, 54, 2375-2388.

Kretz, R. (1983): Symbols for rock-forming minerals. - American Mineralogis, 68, 277-279.

Kudělásková, M. - Kudělásek, V. - Matýsek, D. (1993): Chemické a petrologické studium pikritových hornin z podbeskydské oblasti. - Sborník vědeckých prací Vysoké školy báňské v Ostravě, 39, 63-72. Ostrava.

Leake, B. E. - Woolley, A. R. - Arps, C. E. S. - Birch, W. D. - Gilbert, M. C. - Grice, J. D. - Hawthorne, F. C. - Kato, A. - Kisch, H. J. - Krivovichev, V. G. - Linthout, K. - Laird, J. - Mandarino, J. - Maresch, W. V. - Nickel, E. H. - Rock, N. M. S. - Schumacher, J. C. - Smith, D. C. - Stephenson, N. C. N. - Ungaretti, L. - Whittaker, E. J. W. - Youzhi, G. (1997): Nomenclature of amphiboles. Report of the Subcommittee on Amphiboles of the International Mineralogical Association Commission on New Minerals and Mineral Names. - European Journal of Mineralogy, 9, 623-651.

Lehmann, J. (1983): Diffusion between olivine and spinel: application to geothermometry. - Earth and Planetary Science Letters, $64(1), 123-138$.

Lucińska-Anazkiewicz, A. - Villa, I. M. - Anazkiewicz, R. - Ślaczka, A. (2002): ${ }^{40} \mathrm{Ar} /{ }^{39} \mathrm{Ar}$ dating of alkaline lamprophyres from the Polish Western Carpathians. - Geologica Carpathica, 53, 45-52.

Morimoto, N. - Fabries, J. - Ferguson, A. K. - Ginzburg, I. V. - Ross, M. - Seifert, F. A. - Zussman, J. - Aoki, K. (1988). Nomenclature of pyroxenes. - Mineralogical Magazine 52, 535-550.

Narebski, W. (1990): Early rift stage in the evolution of western part of the Carpathians: geochemical evidence from limburgite and teschenite rock series. - Geologica Carpathica, 41, 521-528.

Nemčok, M. - Nemčok, J. - Wojtaszek, M. - Ludhova, L. - Oszczypko, N. - Sercombe, W. J. - Cieszkowski, M. - Paul, Z. - Coward, M. P. - Slaczka, A. (2001): Reconstruction of Cretaceous rifts incorporated in the Outer West Carpathian wedge by balancing. - Marine and Petroleum Geology, 18 (1), 39-64.

O'Neill, H. St. C. - Wall, V. J. (1987): The olivine-orthopyroxene-spinel oxygen geobarometer, the nickel precipitation curve, and the oxygen fugacity of the Earth's upper mantle. - Journal of Petrology, 28, 1169-1191.

Sato, K. - Katsura, T. - Ito, E. (1997): Phase relations of natural phlogopite with and without enstatite up to 8 GPa: implications for mantle metasomatism. - Earth and Planetary Science Letters, 146, 511-526.

Schumacher, J. C. (1997): Appendix 2: the estimate of ferric iron in electron microprobe analysis of amphiboles. - Canadian Mineralogist, 35, 238-246.

Spišiak, J. - Hovorka D. (1997): Petrology of the Western Carpathians Cretaceous primitive alkaline volcanics. - Geologica Carpathica, 48, 113-121.

Ryan, C. G. - Griffin, W. L. - Pearson, N. J. (1996): Garnet geotherms: pressure-temperature data from Cr-pyrope garnet xenocrysts in volcanic rocks. - Journal of Geophysical Research 101, 5611-5625.

Wlodyka, R. (2010): Ewolucja skladu mineralnego skal cieszynskej provincii magmovej. - Wydawnictwo Univ. Slaskiego, Katowice, $231 \mathrm{pp}$. 